\title{
Avaliação nutricional da polpa de maçã como suplementação energética para bovinos
}

\author{
Nutritional evaluation of apple pulp as energetically supplementation to cattle
}

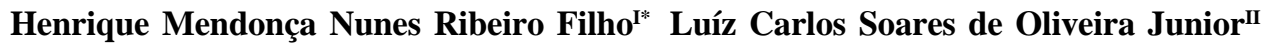 \\ Kamila Maciel Dias ${ }^{\mathrm{I}}$
}

\section{RESUMO}

Objetivou-se avaliar o efeito da suplementação com polpa de maçã, em substituição ao grão de milho, para bovinos ingerindo azevém anual verde. Os tratamentos experimentais foram pasto de azevém à vontade (AZ) ou suplementado com $0,5 \%$ do peso vivo de MS constituída: de grão de milho (AM), de uma mistura de grão de milho + polpa de maçã (50:50; AMP) ou de polpa de maçã (AP). Os animais utilizados foram quatro novilhos machos, castrados, com peso vivo médio de $219 \pm 22,1 \mathrm{~kg}$, dotados de cânula ruminal e distribuídos em um quadrado latino $4 \times 4$, com períodos de 16 dias (10 de adaptação e 6 de coleta). O consumo voluntário de MO da forragem $\left(71,5 \mathrm{~g} \mathrm{~kg}^{-1} \mathrm{PV}^{0,75}\right)$ não se alterou com o uso de suplementação nem com o tipo de suplemento, mas o consumo total de MO e de energia metabolizável aumentaram, respectivamente, $17,4 \mathrm{~g} \mathrm{~kg}^{-1} \mathrm{PV}^{0,75}$ e 9,8MJ dia $\mathrm{d}^{-1}$ nos animais suplementados, sem que houvesse diferença entre os animais recebendo os diferentes tipos de suplementação. $\mathrm{O}$ pH ruminal $(6,7)$, o valor energético das dietas (média $=12,1 \mathrm{MJ} \mathrm{kg}^{-1} \mathrm{MS}$ ) e a síntese de proteína microbiana (média $=414 \mathrm{~g} \mathrm{dia}^{-1}$ ) não se alteraram com o fornecimento da suplementação energética nem com o tipo desta. Entretanto, a digestibilidade do FDA ($10 \%)$ e o consumo de MO digestível $\left(-9,7 \mathrm{~g} \mathrm{~kg}^{-1} \mathrm{PV}^{0,75}\right)$ foram inferiores nos animais ingerindo somente polpa, em comparação aos demais tipos de suplementação. A substituição de até $50 \%$ da MS do grão de milho por polpa de maçã, para bovinos ingerindo pastos de azevém, é uma prática segura quando se objetiva aumentar a ingestão de MO digestível.

Palavras-chave: consumo voluntário, crescimento microbiano, digestibilidade aparente, fermentação ruminal, valor energético.

\section{ABSTRACT}

The aim of this work was to evaluate the effect of supplementation with apple pulp to heifers receiving fresh Italian ryegrass. The treatments were fresh Italian ryegrass $(R)$ ad libidum or supplemented with $0.5 \%$ of DM of body weight as: corn ground $(R C)$, corn ground + apple pulp (50:50; RCP) or apple pulp (RP). Four Holstein steers (mean LW of $219 \pm 22.1 \mathrm{~kg}$ ) with permanent ruminal cannulae, housed in metabolic cages were assigned in a $4 \times 4$ latin square experiment with periods of 16 days (10 for adaptation and 6 for measurements). The OM voluntary intake of herbage was similar in heifers with or without supplementation (average $=71.5 \mathrm{~g} \mathrm{~kg}^{-1} B W^{0.75}$ ), but total OM intake and metabolisable energy intake increased, respectively, $17.4 \mathrm{~g} \mathrm{~kg}^{-1} \mathrm{PV}^{0.75}$ e 9.8MJ day-1 in supplemented heifers compared with the no supplemented ones. The ruminal $\mathrm{pH}$ (average = 6.7), the energetically values of diets (average $=12.0 \mathrm{MJ} \mathrm{kg}^{-1}$ $D M$ ) and microbial protein synthesis (average $414 \mathrm{~g} \mathrm{day}^{-1}$ ) did not change with supplementation. However the ADF digestibility (-10\%) and digestible OM intake $\left(-9.7 \mathrm{~g} \mathrm{~kg}^{-1} \mathrm{BW} \mathrm{W}^{0.75}\right)$ were lower in animals receiving apple pulp only comparing with other supplement types. In conclusion, to improve the digestible OM intake apple pulp can be used to replace until $50 \%$ of DM of corn ground to heifers eating fresh Italian ryegrass.

Key words: apparent digestibility, energetically value, ruminal fermentation, microbial protein synthesis, voluntary intake.

\section{INTRODUÇÃO}

Em sistemas de produção de ruminantes, quando o objetivo é maximizar o aporte de nutrientes a partir das forragens, o uso de alimentos concentrados deve ser efetuado no intuito de se minimizar substituições do pasto pelo suplemento, bem como prover as frações nutritivas deficientes. Nesse aspecto,

'Programa de Pós-graduação em Ciência Animal, Universidade do Estado de Santa Catarina (UDESC), 88520-000, Lages, SC, Brasil. E-mail: a2hrf@cav.udesc.br.*Autor para correspondência.

IIUDESC, Lages, SC, Brasil. 
forragens com elevados teores de proteína bruta, como é o caso do azevém (Lolium multiflorum Lam.), são passíveis de perdas ruminais de $\mathrm{N}$ com possibilidade de redução na quantidade total de proteína que chega ao intestino delgado, em comparação à quantidade ingerida (POPPI \& McLENNAN, 1994). Dessa forma, o uso de fontes de proteína com baixa degradabilidade ruminal (FAVERDIN et al., 2003) ou de suplementos energéticos seria o mais recomendado, ainda que o efeito deste último sobre a eficiência de uso do $\mathrm{N}$ da forragem, em prol de elevações na síntese de proteína microbiana, nem sempre apresente os resultados esperados (YANG et al., 2010).

Os suplementos energéticos mais utilizados, como o grão de milho, são sujeitos a oscilações de preço muitas vezes imprevisíveis. Por outro lado, alguns resíduos de agroindústria, potencialmente utilizáveis na alimentação animal, ainda não foram suficientemente investigados. Um desses coprodutos é a polpa de maçã, oriunda do processamento da maçã para a obtenção de sidras e sucos. Dos cerca de um milhão de toneladas produzidos anualmente no Brasil, estima-se que $25 \%$ seja destinado às indústrias. Dessa fração, entre 20 e $25 \%$ do peso é retido como matéria residual. Em termos qualitativos, ela se caracteriza por apresentar elevada quantidade de açucares solúveis e pectina, mas baixa porcentagem de PB (MANTEROLA et al., 1999).

Objetivou-se avaliar o impacto nutricional do uso da polpa de maçã em substituição ao grão de milho como suplementação energética para bovinos ingerindo azevém anual verde.

\section{MATERIAL E MÉTODOS}

O trabalho foi conduzido no período de julho a setembro/2005, utilizando quatro novilhos da raça Holandesa com peso vivo médio de $219 \pm 22,1 \mathrm{~kg}$, dotados de cânula ruminal e alojados em baias individuais. Os animais foram distribuídos em um quadrado latino $4 \times 4$, ao longo de quatro períodos de 16 dias cada (10 de adaptação e seis de coleta). Durante os períodos de coleta, os animais foram equipados com sacolas para coleção total de fezes e coletores de urina.

Os tratamentos experimentais foram constituídos de azevém anual verde, inteiro e à vontade (Az), azevém anual à vontade + suplementação com grão de milho (AM), azevém anual à vontade + suplementação com uma mistura de grão de milho + polpa de maçã na proporção de 50:50 com base na MS (AMP) e azevém anual à vontade + suplementação com de polpa de maçã (AP). O suplemento foi fornecido em cocho separado da forragem uma vez ao dia, às $7 \mathrm{~h}$.
A forragem foi fornecida duas vezes ao dia (às $7 \mathrm{~h}$ e às 18h). Para isso, o pasto de azevém foi cortado uma vez por dia, às $17 \mathrm{~h}$. Depois de fornecida a refeição da tarde, o restante do azevém foi mantido esparramado sobre piso de concreto em área ventilada com temperatura ambiente até o fornecimento da próxima refeição. A polpa de maçã foi recebida da indústria uma única vez no início do experimento, armazenada em caixa de concreto e coberta com lona plástica para manutenção da anaerobiose, não sendo registrada a presença significativa de bolores ao longo do trabalho. Os teores de MS e PB, FDN e FDA expressos na MS foram, respectivamente, $15,5 \%, 16,4 \% 49,0 \%$ e $29,2 \%$ no azevém anual; 82,0\%, 9,6\%, 12,2\% e 4,2\% no grão de milho; e 20,6\%, 4,3\%, 28,6\% e 21,4\% na polpa de maçã. A quantidade diária distribuída de suplemento foi equivalente a $0,5 \%$ de MS em relação ao peso corporal e a quantidade de forragem foi permanentemente ajustada para permitir sobras equivalentes a $20 \%$ do oferecido no dia anterior.

Para medir o consumo e a digestibilidade dos nutrientes ingeridos, amostras dos alimentos oferecidos foram coletadas do $11^{\circ}$ ao $15^{\circ}$ dia de cada período experimental e amostras das sobras e fezes do $12^{\circ}$ ao $16^{\circ}$ dia. Todas as amostras foram pesadas e secas em estufa de ventilação forçada, moídas e armazenadas para realização das análises laboratoriais.

A síntese de proteína microbiana foi medida a partir do volume produzido de urina e de sua concentração em derivados de purinas. Para isso, do dia 11 ao dia 15 de cada período experimental, toda a urina produzida foi coletada diariamente em recipientes contendo $200 \mathrm{~mL}$ de solução ácido sulfúrico $20 \%$ v/v. O volume produzido de urina foi medido e uma amostra de $1 \%$ do total foi coletada. Essa amostra foi diluída com água destilada em balões volumétricos de $200 \mathrm{~mL}$, congelada e armazenada para realização das análises.

A dinâmica da fermentação ruminal foi monitorada pela medida do $\mathrm{pH}$ e da concentração de amônia. No $16^{\circ}$ dia de cada período experimental, amostras de líquido ruminal foram coletadas às 6h30min, 8h30min, 10h30min, 13h30min, 15h30min e 17h30min. O pH foi medido imediatamente após a coleta. Em seguida, o líquido ruminal foi filtrado em seis camadas de gaze e uma alíquota de $18 \mathrm{~mL}$ foi transferida para recipientes contendo $2 \mathrm{~mL}$ de uma solução de ácido sulfúrico $20 \%$ v/v para determinação da concentração de amônia.

Após a pré-secagem em estufa com ventilação forçada a $60^{\circ} \mathrm{C}$, as amostras de forragem, sobras, suplementos e fezes foram compostas por período e analisadas. Os teores de MS total foram 
determinados por secagem em estufa a $105^{\circ} \mathrm{C}$ até peso constante. As cinzas foram obtidas por incineração a $550^{\circ} \mathrm{C}$ por 3 h. A proteína bruta foi medida por método Kjeldhal (AOAC, 1995; método 984.13). Os teores de fibra em detergente neutro (FDN) foram analisados como proposto por VAN SOEST et al. (1991), com o uso de amilase estável ao calor, mas sem sulfito de sódio. A fibra em detergente ácido (FDA) e os teores de lignina foram determinados segundo VAN SOEST (1981) e as concentrações de FDN e FDA foram expressas incluindo as cinzas residuais.

As amostras de líquido ruminal previamente acidificadas com ácido sulfúrico foram analisadas para determinação da concentração de amônia (WEATHERBURN, 1967) e, nas amostras de urina, as concentrações de ácido úrico e alantoina foram determinadas por colorimetria, conforme proposto por CHEN \& GOMES (1995). A xantina e a hipoxantina foram convertidas em ácido úrico pela ação de xantina oxidase e a sua concentração determinada com o uso de um kit comercial (LABTEST, Lagoa Santa, MG, Brasil). O total dos derivados de purinas (DP) foi quantificado pela soma de ácido úrico + alantoina e a síntese de proteína microbiana foi estimada pela quantidade de purinas absorvidas (mmol dia ${ }^{-1}$ ), a qual foi calculada a partir dos DP excretados, conforme descrito por CHEN \& GOMES (1995).

Os resultados referentes ao consumo de nutrientes, digestibilidade e síntese de proteína microbiana foram submetidos à análise de variância, considerando como fatores os efeitos de animal, tratamento e período experimental. As médias dos tratamentos foram comparadas por meio de contrastes ortogonais, visando a observar o efeito da suplementação (tratamento Az vs. AM, AMP, AP) e dos diferentes tipos de suplemento (tratamento AM vs AMP, AP e AP vs AMP, AM). Para quantificação das diferenças entre tratamentos e horários de amostragens nos parâmetros de fermentação ruminal, foi utilizado um modelo misto (Statistical Analysis System, SAS LITTELL et al., 1998), considerando como efeitos fixos: tratamento, período, horário de coleta e a interação tratamento $\times$ horário de coleta. $O$ efeito de animal foi considerado como aleatório. As análises foram efetuadas considerando as medidas repetidas no tempo, levando em conta o nível de significância de $5 \%$ de probabilidade e a matriz de covariância foi escolhida de acordo com o critério de informação de Akaike (WOLFINGER et al., 1993).

\section{RESULTADOS}

Os consumos voluntários de MS (média = 2,19\% PV), $\mathrm{MO}\left(\right.$ média $=71,5 \mathrm{~g} \mathrm{~kg}{ }^{-1} \mathrm{PV}^{0,75}$ ) $\mathrm{e}$ dos constituintes da MO do azevém não variaram com o fornecimento de nenhum dos tipos de suplementação energética, bem como entre os tipos de suplementação (Tabela 1). De outra forma, o consumo de MS e MO total aumentaram $(\mathrm{P}<0,05)$, respectivamente, $0,4 \%$ do PV e $17,4 \mathrm{~g} \mathrm{~kg}^{-1} \mathrm{PV}^{0,75}$ nos animais suplementados, em comparação aos animais não suplementados, mas não variou entre os diferentes tipos de suplementação.

As digestibilidades aparentes da MS (média $=74 \%$ ) e da MO (média $=77 \%$ ) foram semelhantes nos animais suplementados, em comparação aos não suplementados e entre os tipos de suplementação (Tabela 2). Contudo, a digestibilidade da FDN diminuiu $(\mathrm{P}<0,09)$ aproximadamente 3,0 unidades percentuais nas dietas em que houve presença da suplementação, enquanto a digestibilidade da FDA diminuiu $(\mathrm{P}<0,05)$ aproximadamente 10 unidades percentuais, quando a suplementação foi constituída de somente polpa em comparação aos demais tipos de suplementação.

O valor energético das dietas (média = 12,1MJ em $\mathrm{kg}^{-1} \mathrm{MS}$ ) não se alterou com o fornecimento da suplementação energética nem com o tipo desta. Entretanto, os consumos de MO digestível $\left(+13,4 \mathrm{~g} \mathrm{~kg}^{-1}\right.$ $\mathrm{PV}^{0,75}$ ) e de energia metabolizável $\left(+0,2 \mathrm{MJ} \mathrm{kg}^{-1} \mathrm{PV}^{0,75}\right)$ foram superiores nos animais suplementados, em comparação aos não suplementados. Quando comparados os diferentes tipos de suplemento, observa-se que o consumo de MO digestível foi 9,7g $\mathrm{kg}^{-1} \mathrm{PV}^{0,75}$ inferior $(\mathrm{P}<0,06)$ no tratamento AP, quando comparado a média dos tratamentos AM e AMP.

A síntese de proteína microbiana (média $=414 \mathrm{~g}$ $\left.\mathrm{dia}^{-1}\right)$ e a eficiência do crescimento microbiano (115g $\mathrm{kg}^{-1} \mathrm{MO}$ aparente digestível) não variaram nos animais suplementados em comparação aos não suplementados, assim como nos animais recebendo os diferentes tipos de suplemento. Da mesma forma, o $\mathrm{pH}$ ruminal foi semelhante (média $\mathrm{pH}=6,8$ ) nos animais recebendo os diferentes tipos de dieta, mas a concentração de $\mathrm{N}-\mathrm{NH}_{3}$ diminuiu $(\mathrm{P}<0,05)$ nos animais que receberam polpa de maçã ou polpa de maçã mais grão de milho, em comparação com os que receberam somente grão de milho como suplementação.

Não houve efeito da interação tipo de dieta $\times$ horário do dia no tocante aos parâmetros de fermentação ruminal avaliados (Figura 1). Em todos os tratamentos, após a refeição da manhã (7h30min), o pH ruminal diminui de aproximadamente 7,2 para valores um pouco acima de 6,4 , às $11 \mathrm{~h} 30 \mathrm{~min}$. No tocante às concentrações ruminais de $\mathrm{N}-\mathrm{NH}_{3}$, os maiores valores foram observados duas horas após a refeição da manhã (média $=3,5 \mathrm{mmol}$ $\mathrm{L}^{-1}$ ) e os menores nas coletas realizadas antes da refeição da tarde (média $=1,8 \mathrm{mmol} \mathrm{L}^{-1}$ ). 
Tabela 1 - Consumo de nutrientes em novilhos ingerindo azevém anual à vontade com ou sem suplementação com grão de milho e/ou polpa de maçã na proporção de $0,5 \%$ de MS em relação ao peso vivo.

\begin{tabular}{|c|c|c|c|c|c|c|c|c|}
\hline & \multicolumn{5}{|c|}{ 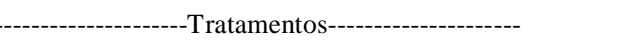 } & \multicolumn{3}{|c|}{---Contrastes $(\mathrm{P}<$ )-- } \\
\hline & $\mathrm{Az}$ & $\mathrm{AM}$ & AMP & AP & dpr & $\begin{array}{c}\text { s/supl } \\
v s \\
\text { c/supl. }\end{array}$ & $\begin{array}{l}\text { s/polpa } \\
\text { vs } \\
\text { c/polpa }\end{array}$ & $\begin{array}{l}\text { s/milho } \\
v s \\
\text { c/milho }\end{array}$ \\
\hline $\begin{array}{l}\text { Matéria seca } \\
(\% \mathrm{PV})\end{array}$ & 2,19 & 2,16 & 2,20 & 2,19 & 0,25 & NS & NS & NS \\
\hline $\begin{array}{l}\text { Material orgânica } \\
\left(\mathrm{g} \mathrm{kg}^{-1} \mathrm{PV}^{0,75}\right)\end{array}$ & 71,9 & 70,2 & 72,2 & 71,7 & 8,27 & NS & NS & NS \\
\hline $\begin{array}{l}\text { Proteína bruta } \\
\left(\mathrm{g} \mathrm{kg}^{-1} \mathrm{PV}^{0,75}\right)\end{array}$ & 13,8 & 13,5 & 13,7 & 13,6 & 1,17 & NS & NS & NS \\
\hline $\begin{array}{l}\text { Fibra em detergente neutro } \\
\left(\mathrm{g} \mathrm{kg}^{-1} \mathrm{PV}^{0,75}\right)\end{array}$ & 50,0 & 48,4 & 50,7 & 50,2 & 6,35 & NS & NS & NS \\
\hline $\begin{array}{l}\text { Fibra em detergente ácido } \\
\left(\mathrm{g} \mathrm{kg}^{-1} \mathrm{PV}^{0,75}\right)\end{array}$ & 24,7 & 23,9 & 24,9 & 21,4 & 5,91 & NS & NS & NS \\
\hline $\begin{array}{l}\text { Matéria seca } \\
(\% \mathrm{PV})\end{array}$ & 2,20 & 2,67 & 2,62 & 2,46 & 0,26 & $*$ & NS & NS \\
\hline $\begin{array}{l}\text { Material orgânica } \\
\left(\mathrm{g} \mathrm{kg}^{-1} \mathrm{PV}^{0,75}\right)\end{array}$ & 71,9 & 88,5 & 86,8 & 81,1 & 8,67 & $*$ & NS & NS \\
\hline $\begin{array}{l}\text { Proteína bruta } \\
\left(\mathrm{g} \mathrm{kg}^{-1} \mathrm{PV}^{0,75}\right)\end{array}$ & 13,8 & 15,3 & 15,2 & 14,5 & 1,24 & NS & NS & NS \\
\hline $\begin{array}{l}\text { Fibra em detergente neutro } \\
\left(\mathrm{g} \mathrm{kg}^{-1} \mathrm{PV}^{0,75}\right)\end{array}$ & 50,0 & 50,8 & 55,6 & 53,2 & 6,4 & NS & NS & NS \\
\hline $\begin{array}{l}\text { Fibra em detergente ácido } \\
\left(\mathrm{g} \mathrm{kg}^{-1} \mathrm{PV}^{0,75}\right)\end{array}$ & 24,7 & 24,8 & 29,1 & 26,4 & 6,23 & NS & NS & NS \\
\hline
\end{tabular}

$\mathrm{Az}$ = somente azevém; AM = azevém + grão de milho quebrado na proporção de 0,5\% de MS em relação ao peso corporal; AMP = azevém + grão de milho e polpa de maçã (50:50) na proporção de 0,5\% do peso corporal; AP = azevém + polpa de mação na proporção de $0,5 \%$ de MS em relação ao peso corporal; dpr = desvio padrão residual; ${ }^{1}$ Efeito do contraste com suplementação vs sem suplementação; ${ }^{2}$ Efeito do contraste somente milho vs milho:polpa (50:50) ou somente polpa; ${ }^{3}$ Efeito do contraste somente polpa vs milho:polpa (50:50) ou somente milho; NS $=\mathrm{P}>0,10 ; *=\mathrm{P}<0,05$.

\section{DISCUSSÃO}

As características dos alimentos utilizados demonstram que a forragem apresentou relação de $250 \mathrm{~g}$ $\mathrm{PB} \mathrm{kg}^{-1} \mathrm{MO}$ digestível, a qual é suficiente para não impor limitação nitrogenada ao crescimento (POPPI \& McLENNAN, 1995). No que diz respeito à composição químico bromatológica da polpa de maçã, a amplitude de variação citada por outros autores (MANTEROLA et al., 1999) indica teores de MS entre 14 e $26 \%$, e de PB entre 4 e $8 \%$. Dessa forma, pode-se afirmar que o coproduto utilizado neste experimento é típico em relação ao normalmente obtido em outras indústrias beneficiadoras do fruto.

A inexistência de alteração no consumo de forragem e a consequente existência de efeito aditivo da suplementação sobre a ingestão de MO total e de MO digestível provavelmente ocorreu devido ao baixo nível de suplementação utilizado. Além disso, o consumo voluntário de MS da forragem (aproximadamente 2,2\% PV) foi coerente com o valor de FDN relativamente baixo e condizente com o esperado em forragens de boa qualidade, uma vez que bovinos em crescimento com esse nível de ingestão são capazes de obter ganho médio diário acima de 1,0kg $\mathrm{dia}^{-1}$, quando recebendo pastos de clima temperado (INRA, 1989).

É necessário considerar, contudo, que, quando os animais receberam a polpa como única fonte de suplementação energética, o consumo de MO digestível reduziu, em comparação aos demais tipos de suplementação. Isso certamente ocorreu por que, diferente dos demais tratamentos, quando a polpa foi fornecida de maneira isolada, frequentemente eram observadas sobras do alimento concentrado. Embora esta diferença não tenha sido suficiente para que fosse observada alguma redução significativa na ingestão de energia metabolizável, os 
Tabela 2 - Consumo de MO digestível (MOD), energia metabolizável (EM), síntese de proteína microbiana e parâmetros de fermentação ruminal em bovinos recebendo azevém anual com ou sem suplementação energética na proporção de 0,5\% de MS em relação ao do peso vivo.

\begin{tabular}{|c|c|c|c|c|c|c|c|c|}
\hline & \multicolumn{5}{|c|}{ 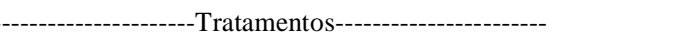 } & \multirow[b]{2}{*}{$\begin{array}{c}\text { s/supl } \\
\text { vs } \\
\text { c/supl. }{ }^{1}\end{array}$} & trastes $(\mathrm{P}$ & \multirow[b]{2}{*}{$\begin{array}{c}\text { s/milho } \\
\text { vs } \\
\text { c/milho }\end{array}$} \\
\hline & $\mathrm{Az}$ & $\mathrm{AM}$ & AMP & AP & dpr & & $\begin{array}{c}\text { s/polpa } \\
\text { vs } \\
\text { c/polpa }\end{array}$ & \\
\hline ------. & ----- & ------ & ------I & ibilidad & - & - & -.--- & -------' \\
\hline Matéria seca & 74,7 & 74,2 & 74,4 & 74,1 & 1,59 & NS & NS & NS \\
\hline Matéria orgânica & 76,6 & 76,2 & 76,3 & 76,0 & 1,72 & NS & NS & NS \\
\hline FDN & 79,7 & 76,5 & 77,9 & 75,9 & 2,53 & 0,09 & NS & NS \\
\hline FDA & 78,4 & 76,0 & 77,0 & 71,1 & 4,00 & NS & NS & $*$ \\
\hline $\mathrm{EM}\left(\mathrm{MJ} \mathrm{kg}^{-1} \mathrm{MS}\right)$ & 12,0 & 12,0 & 12,4 & 12,0 & 0,30 & NS & NS & NS \\
\hline $\begin{array}{l}\text { MO digestível } \\
\text { (kg/dia) }\end{array}$ & 3,2 & 3,8 & 4,4 & 3,6 & 0,39 & * & NS & 0,07 \\
\hline $\begin{array}{l}\text { MO digestível } \\
\left(\mathrm{g} \mathrm{kg}^{-1} \mathrm{PV}^{0,75}\right)\end{array}$ & 55,5 & 67,4 & 76,9 & 62,5 & 6,56 & $*$ & NS & 0,06 \\
\hline $\mathrm{EM}\left(\mathrm{MJ} \mathrm{kg}^{-1} \mathrm{PV}^{0,75}\right)$ & 1,03 & 1,22 & 1,25 & 1,14 & 0,12 & $*$ & NS & NS \\
\hline Total (g dia $\left.{ }^{-1}\right)$ & 332 & 462 & $\begin{array}{c}\text {-Síntes } \\
488\end{array}$ & $\begin{array}{c}\text { oteína } \\
374\end{array}$ & $\begin{array}{r}\text { biana---- } \\
134,2\end{array}$ & NS & NS & NS \\
\hline $\begin{array}{l}\text { MO digestível } \\
\left(\mathrm{g} \mathrm{kg}^{-1}\right)\end{array}$ & 110 & 125 & 112 & 111 & 30,8 & NS & NS & NS \\
\hline $\mathrm{pH}$ ruminal & 6,8 & 6,8 & 6,7 & 6,7 & 0,07 & NS & NS & NS \\
\hline $\begin{array}{l}\mathrm{N}-\mathrm{NH}_{3} \\
\left(\mathrm{mmol} 100 \mathrm{~mL}^{-1}\right)\end{array}$ & 2,54 & 2,80 & 2,19 & 2,16 & 0,359 & NS & $*$ & NS \\
\hline
\end{tabular}

$\mathrm{Az}=$ somente azevém; $\mathrm{Az}+\mathrm{M}$ = azevém + grão de milho quebrado na proporção de 0,5\% de MS em relação ao peso corporal; Az + MP = azevém + grão de milho e polpa de maçã (50:50) na proporção de 0,5\% de MS do peso corporal; Az $+\mathrm{P}=$ azevém + polpa de maçã na proporção de $0,5 \%$ de MS em relação ao peso corporal; $d p r=$ desvio padrão residual; ${ }^{1}$ Efeito do contraste com suplementação vs sem suplementação; ${ }^{2}$ Efeito do contraste somente milho vs milho:polpa (50:50) ou somente polpa; ${ }^{3}$ Efeito do contraste somente polpa vs milho:polpa (50:50) ou somente milho; EM = energia metabolizável: estimada a partir da digestibilidade aparente da MO, conforme proposto pelo AFRC (1993); NS = P >0,10; * $=\mathrm{P}<0,05$.

resultados evidenciam que se deve ter cautela quanto a recomendações de uso de polpa de maçã como suplementação energética exclusiva, sobretudo em níveis superiores a $0,5 \%$ do peso vivo.

A elevação no consumo diário de energia nos animais suplementados, em comparação aos não suplementados, foi função da manutenção da ingestão de $\mathrm{MO}$ da forragem. Considerando que a digestibilidade aparente da MO não se alterou com a presença nem com o tipo de suplementação, fica evidente que a tendência de redução $(\mathrm{P}=0,09)$ na digestibilidade do FDN nos animais suplementados em comparação aos não suplementados foi insuficiente para que ocorresse redução na energia digestível da dieta. Esses resultados podem ser parcialmente explicados pela manutenção do pH ruminal acima de 6,4, independente do tratamento experimental. Segundo STROBELL \& RUSSELL (1986), reduções na digestibilidade da fibra se tornam evidentes quando o fornecimento de concentrado é suficiente para reduzir o pH ruminal a valores abaixo de 6,0.
Embora a presença da polpa de maçã na suplementação tenha contribuído para reduções nas concentrações de $\mathrm{N}-\mathrm{NH}_{3}$ ruminal, o crescimento microbiano não foi afetado. Contudo, devido ao elevado desvio padrão residual observado para esta variável, recomenda-se cautela na interpretação dos resultados. Conforme revisão de literatura realizada por DEWHURST et al. (2000), é esperado que o uso de animais canulados no rúmen aumente consideravelmente a variação individual na obtenção de amostras para as medidas de síntese de proteína microbiana, o que implica, em muitos casos, a necessidade de se utilizar um número excessivo de animais para que diferenças significativas possam ser observadas (TITGEMEYER, 1997). Esses comentários são necessários porque a suplementação com polpa de maçã isolada, sobretudo em maiores níveis de fornecimento, poderia implicar reduções no desempenho animal, tanto pela menor ingestão MO digestível como pelo menor aporte de proteína 


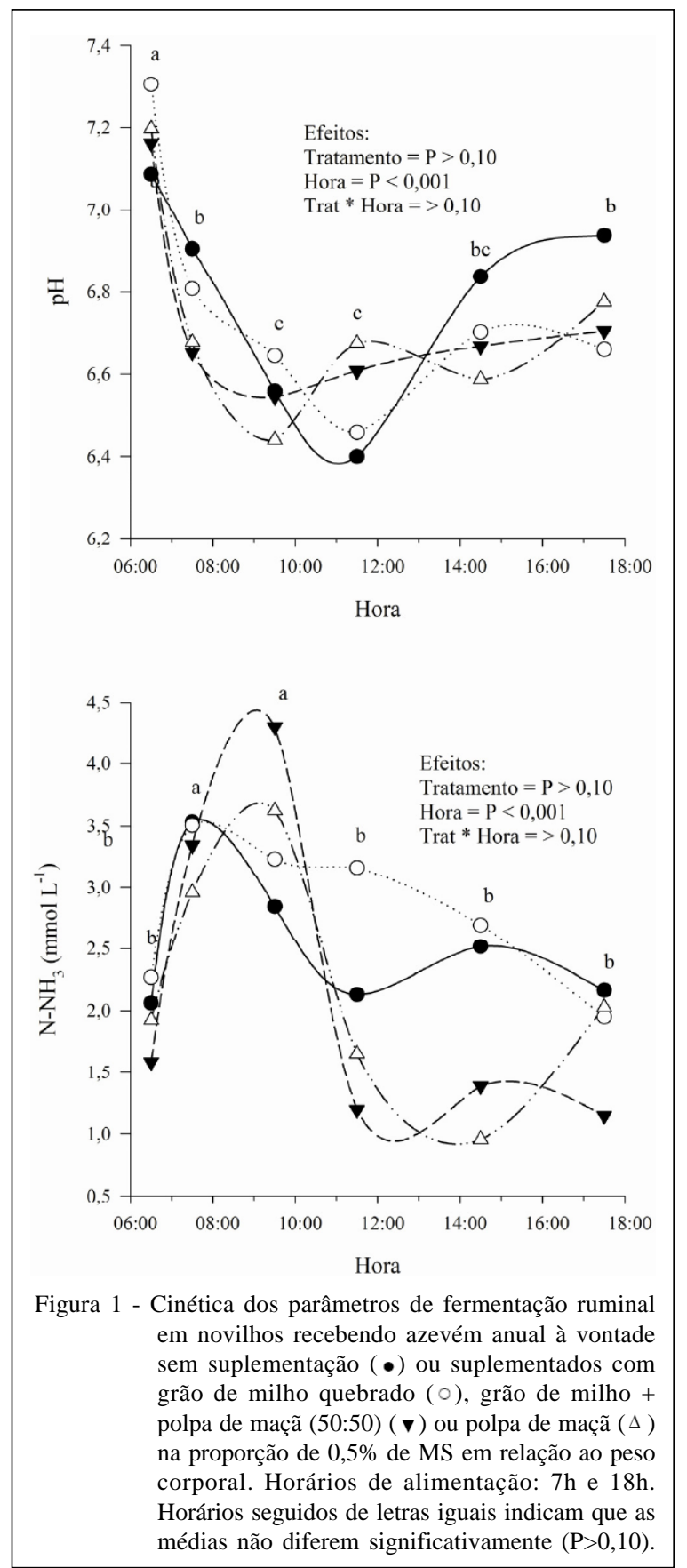

metabolizável, em comparação a sua mistura com grão de milho. Nesse sentido, a substituição de $50 \%$ do grão de milho por polpa parece uma recomendação segura, uma vez que a síntese de proteína microbiana observada nos animais submetidos à dieta AMP seria de aproximadamente $490 \mathrm{~g} \mathrm{dia}^{-1}$, ou seja, cerca de $120 \mathrm{~g}$ a mais em comparação aos animais que receberam a polpa como única fonte de suplementação energética.

Do ponto de vista prático, a absorção intestinal de proteína microbiana estimada no tratamento AMP, associada à proteína não degradável da forragem, permitiria um aporte de proteína metabolizável suficiente para vacas leiteiras produzirem ao redor de $25 \mathrm{~kg}$ de leite por dia, sem ganhar nem perder peso (INRA, 1989; AFRC, 1993). Contudo, elevações no fornecimento da polpa poderiam implicar reduções na ingestão de MO digestível e diminuição do crescimento microbiano em comparação ao uso da polpa associada ao grão e milho. Esses resultados podem ser a base para explicação de recomendações

Ciência Rural, v.42, n.9, set, 2012. 
onde a proporção de polpa deve ser reduzida, à medida que aumenta o potencial de produção da vaca (BATH, 1981; EDWARDS \& PARKER, 1995). Segundo esses autores, produções de leite na faixa 12 a $15 \mathrm{~kg} \mathrm{dia}^{-1}$ permitem a utilização de polpa de maçã em até $40 \%$ da MS total (EDWARDS \& PARKER, 1995), mas essa quantidade não deve ultrapassar a 17-18\% da MS total da dieta para vacas com produções acima de $25 \mathrm{~kg} \mathrm{dia}^{-1}$ (BATH, 1981). Neste trabalho, a proporção de MS da polpa na dieta foi aproximadamente $15 \%$ da MS total.

\section{CONCLUSÃO}

A substituição de até $50 \%$ da MS do grão de milho por polpa de maçã para bovinos ingerindo azevém anual é uma prática segura, quando se objetiva aumentar a ingestão de MO digestível e o aporte intestinal de proteína de origem microbiana.

\section{COMITÊ DE ÉTICA E BIOSSEGURANÇA}

Protocolo nํㅜ 1.04/04 na UDESC.

\section{REFERÊNCIAS}

AFRC. Energy and protein requeriments of ruminants An advisory manual prepared by the AFRC Technical Committee on Reponses to Nutrients. Wallingford, UK: Cab International, 1993. 159p.

ASSOCIATION OF OFFICIAL ANALYTICAL CHEMISTS (AOAC). Offcial methods of analysis of the Association of Offcial Analytical Chemists. Arlington, 1995. 1094p.

BATH, I. Feed by-products and their utilization by ruminants. In: HUBER, T. (Ed.). Upgranding residues and by-products for animals. Madison: CRC, 1981. p.2-16.

CHEN, X.B.; GOMES, M.J. Estimation of microbial protein supply to sheep and cattle based on urinary excretion of purine derivatives - An overview of the technical details. Aberdeen: Internatinal Feed Resources Unit Rowet Research Institute, 1995. 21p. Disponível em: <http:// www.macaulay.ac.uk/IFRU/pdf/chema.pdf>. Acesso em: 31 maio, 2011

DEWHURST, R.J. et al. Microbial protein supply from the rumen. Animal Feed Science Technology, v.85, n.1-2, p.121. 2000. Disponível em: <http://dx.doi.org/10.1016/S03778401(00)00139-5>. Acesso em: 30 maio, 2012. doi: 10.1016/ S0377-8401(00)00139-5.

EDWARDS, J.; PARKER, W. Apple pomace as a supplement to pasture for dairy cows in late lactation. Proceedings of the New Zealand Society of Animal Production, v.55, p.67-69, 1995. Disponível em: <http://nzsap.org.nz/proc/1995/ ab95023.html>. Acesso em: 31 maio, 2012.

FAVERDIN, P. et al. La nutrition azotée influence l'ingestion chez la vache laitière. INRA Production Animal, v.16, n.1, p.27-37. 2003. Disponível em: <http://www6.inra.fr/
productions-animales/2003-Volume-16/Numero-1-2003/Lanutrition-azotee-influence-l-ingestion-chez-la-vache-laitiere>. Acesso em: 31 maio, 2012.

INSTITUT NATIONAL DE LA RECHERCHE AGRONOMIQUE. Ruminant nutrition: recommended allowances and feed tables. London: John Libbey, 1989. 389p.

LITTELL, R.C. et al. Statistical analysis of repeated measures data using SAS procedures. Journal of Animal Science, v.76, p.1216-1213, 1998. Disponível em: <http://jas.fass.org/ content/76/4/1216.full.pdf+html>. Acesso em: 31 maio, 2012.

MANTEROLA, H. et al. Los residuos agrícolas y su uso en la alimentación de rumiantes. Santiago: Ministerio de Agricultura y Fundación para la Innovación Agraria, 1999. 222p.

POPPI, D.P.; McLENNAN, S.R. Protein and energy utilization by ruminants at pasture. Journal of Animal Science, v.73, p.278-290, 1995. Disponível em: <http://jas.fass.org/content/ 73/1/278.full.pdf+html? sid=6c57eb52-e4e3-4871-8b5aa81aa414433b>. Acesso em: 31 maio, 2012.

STROBEL, H.J.; RUSSEL, J.B. Effects of pH and energy spiling on bacteria protein synthesis by carbohydrate limited cultures of mixes rumen bacteria. Journal of Dairy Science, v.69, p.2941, 1986. Disponível em: <http://download.journals.elsevierhealth.com/pdfs/ journals/0022-0302/PIIS0022030286807500.pdf $>$. Acesso em: 31 mai. 2012. doi: 10.3168/jds.S0022-0302(86)80750-0.

TITGEMEYER, E.C. Desing and interpretation of nutrient digestion studies. Journal of Animal Science, v.75, n.8, p.2235-2247, 1997. Disponível em: <http://jas.fass.org/ content $/ 75 / 8 / 2235$.full.pdf + html ? sid $=91 \mathrm{fd} 47 \mathrm{fa}-91 \mathrm{c} 8-4 \mathrm{fc} 2$ 884e-5d4cb61aec13>. Acesso em: 31 maio, 2012.

VAN SOEST, P.J. et al. Methods for dietary fiber, neutral detergent fiber, and nonstarch polysaccharides in relation to animal nutrition. Journal of Dairy Science, v.74, n.10, p.3583-3597, 1991. Disponível em: <http://www.journalofdairyscience.org/article/ S0022-0302(91)78551-2/abstract>. Acesso em: 31 maio. 2012. doi: 10.3168/jds.S0022-0302(91)78551-2.

VAN SOEST, P.J. Limiting factors in plant residues of low biodegradability. Agricultural and Environmental, v.6, p.135143, 1981. Disponível em: <http://www.sciencedirect.com/ science/article/pii/0304113181900059>. Acesso em: 31 maio, 2012. doi: 10.1016/0304-1131(81)90005-9.

WEATHERBURN, M.W. Phenol-hypochlorite reaction for determination of ammonia. Analytical Chemistry. v.39, p.971-974, 1967. Disponível em: <http://pubs.acs.org/doi/abs/ 10.1021/ac60252a045>. Acesso em: 31 maio, 2012. doi: $10.1021 /$ ac60252a045.

WOLFINGER, R.D. Covariance structure selection in general mixed models. Communications in Statistics Simulation and Computation, v.22, n.4, p.1079-1106, 1993. Disponível em: <http:/ /www.tandfonline.com/doi/abs/10.1080/03610919308813143>. Acesso em: 31 maio, 2012. doi: 10.1080/03610919308813143.

YANG, Y.J. et al. Nutrient synchrony: is it suitable strategy to improve nitrogen utilization and animal performance? AsianAustralian Journal of Animal Science, v.23, n.7, p.972979, 2010. Disponível em: <http://www.ajas.info/Editor/ manuscript/upload/23-127.pdf>. Acesso em: 31 maio, 2012. 